ROCZNIKI TEOLOGICZNE

Tom LXVII, zeszyt 3 - 2020

DOI: https://doi.org/10.18290/rt.2067.3-4

\author{
KS. JAROSŁAW WOJTKUN
}

\title{
KONTYNUACJA MYŚLI HUMANAE VITAE \\ W POSYNODALNEJ ADHORTACJI AMORIS LAETITIA CZY NOWA INTERPRETACJA MORALNOŚCI?
}

\author{
CONTINUING THE THOUGHT HUMANAE VITAE \\ IN THE POST-SYNODAL ADHORTATION AMORIS LAETITIA \\ OR A NEW INTERPRETATION OF MORALITY?
}

\begin{abstract}
Humanae vitae, there was a demand to read it again in the light of the method proposed by Pope Francis in the exhortation Amoris laetitia. The new reading of the teachings of Pope Paul VI should take into account a new perspective: not from moral norms, but from the description of the reality in which the spouses find themselves. This new reading optics of Humanae vitae outlined in Amoris laetitia raises the question: is the teaching of Pope Francis a continuation or a new interpretation of morality? There are clear differences in taking such issues as: the essence of sin, its horizontal and vertical dimension, the existence of internally evil acts. Contrary to Paul VI, Francis takes the question of conscience and its role in moral choices. It is hard to resist the impression that the concept of creative conscience, definitely rejected by John Paul II, appears in the moral justifications of Pope Francis. We can also come across fragments of Pope Francis' exhortation, which may prove that he was on the side of the concept of the gradation of law, also rejected in the teaching of the Church so far. Various ways of interpreting certain aspects of moral teaching lead to the conclusion that the exhortation of Francis in many points does not indicate the continuation of the moral doctrine, but is a proposal for a new paradigm of morality.
\end{abstract}

Translated by Jarostaw Wojtkun

Key words: marriage; norm; sin; conscience; law of gradation.

Ks. dr JarosŁaw WojtKun, Katedra Teologii Moralnej Społecznej, Instytut Nauk Teologicznych, Katolicki Uniwersytet Lubelski Jana Pawła II; adres do korespondencji - e-mail: jaroslaw.wojtkun@kul.pl; ORCID: https://orcid.org/0000-0002-3969-3954. 
Już w dniu ogłoszenia encykliki Humanae vitae 25 lipca 1968 roku Paweł VI liczył się z trudnościami, z jakimi może być przyjęta zawarta w niej nauka na temat niedopuszczalności antykoncepcji. „Z góry da się przewidzieć, że nie wszyscy chyba łatwo przyjmą podaną naukę, skoro już podniosło się tyle głosów, które korzystając z pomocy nowoczesnych środków propagandy, sprzeciwiają się nauce Kościoła"1. Paweł VI zdawał sobie sprawę z tego, jak silne są prądy kulturowe, które naznaczyły koniec lat sześćdziesiątych ubiegłego wieku. Utopia szczęścia obiecana przez rewolucję seksualną i oczekiwanie na wzrost dobrobytu wynikający z zahamowania przyrostu naturalnego były nurtami, które uderzyły $\mathrm{w}$ tezy zawarte $\mathrm{w}$ encyklice $\mathrm{z}$ niespotykana gwałtownością ${ }^{2}$. Obawy papieża potwierdziły się, choć skala oporu była dla niego źródłem osobistego cierpienia. Brutalność języka, którym były formułowane komentarze, dotknęły papieża na tyle głęboko, że po 1968 roku nie napisał już żadnej encykliki. Encyklika Pawła VI Humane vitae była przedstawiana jako wyraz dyletanctwa teologicznego, nie mającego potwierdzenia w danych naukowych. Brak przyzwolenia na antykoncepcję miał świadczyć o bezduszności papieża i zamknięciu się na ducha czasu.

Po pięćdziesięciu latach tony dezaprobaty nie umilkły. Dochodzą do głosu również dzisiaj i brzmią jeszcze dobitniej. Areną krytyki może być nawet forum ONZ, na którym grupa katolików wezwała biskupów do zmiany stanowiska Kościoła w sprawie antykoncepcji. Odmawia się Kościołowi prawa do głoszenia nauki na temat antykoncepcji, skoro nie ma go w Piśmie Świętym. Niektórzy posuwają się do sformułowania tezy o etycznym imperatywie sięgania po antykoncepcję. Radykalizm dążeń zmierzających do unieważnienia encykliki Humanae vitae nie zatrzymał się nawet przed uznaniem dopuszczalności metod antykoncepcyjnych prowadzących do aborcji. W odpowiedzi na te postulaty na Katolickim Uniwersytecie Ameryki w Waszyngtonie we wrześniu 2016 roku pojawiła się „kontrdeklaracja” w obronie nauczania encykliki Pawła VI. Ponad pięciuset uczonych uznało zakaz antykoncepcji sformułowany przez Pawła VI za głos proroczy ${ }^{3}$.

Wobec tych faktów aktualne jest pytanie: Czy minione pół wieku od ogłoszenia Humanae vitae zmieniło coś w kluczu lektury papieskiego dokumentu?

${ }^{1} \mathrm{HV} 18$.

2 Por. L. SCARAFFA, Humanae vitae cinquant'anni dopo, „L'Osservatore Romano” 25.07. 2018, s. 1.

${ }^{3}$ Obszerne omówienie tego wydarzenia znajduje się na stronie www.pch24.pl w artykułach: Ponad 500 katolickich naukowców w obronie encykliki „Humanae vitae” i za zakazem antykoncepcji oraz Od buntu wobec „Humanae vitae” do apologii „Amoris laetitia” [2.01.2019]. 
Czy nauczanie Papieża sprzed pięćdziesięciu lat ma dziś moc kształtować rzeczywistość, czy może raczej nowa rzeczywistość sugeruje zmianę metody nauczania moralnego Kościoła? Głosy pojawiające się w debacie z okazji 50. rocznicy ogłoszenia encykliki zdają się opowiadać po drugiej stronie postawionego pytania. Taki wydźwięk miały wypowiedzi w czasie zorganizowanej na rzymskim Uniwersytecie Gregorianum serii kolokwiów poświęconych Humanae vitae ${ }^{4}$. Co prawda nikt nie mówił o weryfikacji nauczania encykliki Pawła VI, jedynie o zmianie metody jej lektury. Jest ona podyktowana całkiem nowym kontekstem kulturowym i społecznym, w jakim żyją rodziny w dzisiejszym świecie.

\section{NOWY KLUCZ DO LEKTURY HUMANAE VITAE?}

Postulat nowego klucza do lektury encykliki Pawła VI pojawił się w związku z ogłoszeniem przez papieża Franciszka adhortacji Amoris laetitia. Według zaproponowanej przez papieża Franciszka odmiennej duszpasterskiej optyki należałoby teraz dokonać ponownej lektury dokumentu Pawła VI ${ }^{5}$. Różnice w metodologii podejmowania zagadnień moralnych obydwu dokumentów widoczne są gołym okiem. Papież Paweł VI wychodził z założenia prymatu prawa naturalnego wobec konkretnych uwarunkowań, w jakich znajduje się człowiek. Struktura przekazywania życia wyraża głęboką strukturę rzeczywistości opisaną naturalnym prawem moralnym. Małżonkowie powinni respektować zawarte w nim zasady określające porządek zadań rodzicielskich. Punktem wyjścia jest tu zasada, prawo moralne. $\mathrm{Z}$ niej dedukujemy sposób podejmowania działań rodzicielskich oraz rozwiązania stosowane w duszpasterstwie małżeństw i rodzin. Norma stanowi punkt odniesienia niezbędny do określenia wartości moralnej czynu.

W adhortacji Amoris laetitia mamy do czynienia ze zmianą perspektywy. Papież Franciszek inaczej rozkłada akcenty. Jeśli określa znaczenie węzła małżeńskiego, to czyni to nie z perspektywy czysto jurydycznej (zasady, normy), lecz perspektywy miłości, której węzeł małżeński jest wyrazem. Taki kierunek powinien określać styl duszpasterstwa małżeństw i rodzin. „Duszpasterstwo przedmałżeńskie i duszpasterstwo małżeństw powinny być przede wszystkim duszpasterstwem więzi, gdzie wnoszone są elementy, które poma-

\footnotetext{
${ }^{4}$ Program cyklu wykładów zorganizowanych z okazji 50. rocznicy Humane vitae dostępny jest na stronie Uniwersytetu Gregoriańskiego w Rzymie www.unigre.it.

${ }^{5}$ Por. L. MoIA, Discutere Humanae vitae? «No, riflettiamo sui temi». Sessualità e famiglia a 50 anni dall'enciclica Alla Gregoriana un percorso per fare chiarezza, „L'Avvenire” 19.10.2017, s. 20.
} 
gają zarówno w dojrzewaniu miłości, jak i w przezwyciężaniu chwil trudnych. Tym wkładem są nie tylko przekonania doktrynalne"6. Także duchowość małżeńska powinna uwzględniać ten porządek. „Ostatecznie duchowość małżeńska jest duchowością więzi, zamieszkałą przez Bożą miłość”7.

Jednym z terminów, które stanowią klucz do lektury adhortacji papieża Franciszka jest „rozeznanie”. Punktem wyjścia nie są normy, a to one w dokumencie Pawła VI stanowią kryterium moralnych uzasadnień. W adhortacji Amoris laetitia spotkamy się z odmienną metodą: najpierw analiza rzeczywistości, a potem zasady. Trzeba najpierw dokonać rozeznania sytuacji. Analiza rzeczywistości jest uprzednia wobec doktryny. W świetle tej analizy dokonujemy rozeznania sytuacji, poszukujemy rozwiązania wynikających z niej problemów i określamy zasady ich rozstrzygania. „Rozeznanie musi pomóc w znalezieniu możliwych dróg odpowiedzenia Bogu i rozwoju pośród ograniczeń. Wierząc, że wszystko jest białe lub czarne, czasami zamykamy drogę łaski i wzrostu oraz zniechęcamy do wysiłków na rzecz świętości, które oddają chwałę Bogu" ${ }^{8}$. Zasady moralne nie są w stanie określić każdej sytuacji i związanych z nimi powinności. Rozeznanie musi uwzględniać konkretną sytuację i rzeczywistość, w jakiej znajduje się człowiek. Zmiana kierunku w stosunku do metodologii Humane vitae jest tu dosyć czytelna. Nie zasady przekazywane przez doktrynę moralną Kościoła są punktem wyjścia, są one teraz punktem dojścia. Punktem wyjścia jest opis rzeczywistości, wraz z jej zmiennością i problemami, punktem dojścia zaś sposób ich rozwiązywania. Zasady są następstwem opisu rzeczywistości.

Taką metodologię lektury dokumentu papieża Franciszka zdaje się sugerować kardynał Joseph Farrel, prefekt Dykasterii ds. Świeckich, Rodziny i Życia. Zauważa najpierw punkty styczne dwóch dokumentów. Łączy je opór, z jakim zostały przyjęte przez niektóre środowiska ${ }^{9}$. Wynikał on z redukcyj-

${ }^{6}$ AL 211.
${ }^{7}$ AL 315.
${ }^{8}$ AL 305.

${ }^{9}$ Za S. CennuzIo, „L'Amoris Latitia” non mette in crisi la famiglia; è la crisi della famiglia che mette in moto la Chiesa. Il cardinale Farrell commenta l'esortazione del Papa, https://www.lastampa.it/2017/03/20/vaticaninsider/ita/vaticano/lamoris-laetitia-non-mette-in-crisila-famiglia-la-crisi-della-famiglia-che-mette-in-moto-la-chiesa[26.03.2019]. Niewszyscypodzielają taki sposób zestawiania obydwu dokumentów. Owszem, zarówno encyklika Pawła VI jak i adhortacja Franciszka rodziły opór recepcyjny. Pochodził on jednak z odmiennych środowisk. Ci, którzy dzisiaj mają trudności w przyjęciu argumentacji Amoris laetitia, należą raczej do obrońców nauczania Humane vitae. Ponadto, papieżowi Pawłowi VI zarzucano arbitralność decyzji o zakazie antykoncepcji, wbrew stanowisku większości w ustanowionej przezeń komisji. 
nego klucza do ich lektury. O ile Humanae vitae sprowadzona została do zakazu antykoncepcji, o tyle w Amoris laetitia dostrzegano tylko problem dostępu do sakramentów rozwiedzionych znajdujących się w związkach cywilnych. Poluzowanie dotychczasowej dyscypliny miałoby podważać zasadę nierozerwalności małżeństwa i prowadzić do kryzysu rodziny. Kardynał jest jednak zdania, że to „nie Amoris laetitia prowadzi do kryzysu rodziny, ale kryzys rodziny uruchamia [mette in moto] Kościół”. Adhortacja papieża Franciszka jest więc reakcją Kościoła na kryzysową sytuację rodziny. Analiza rzeczywistości jest tu, jak widać, punktem wyjścia do proponowanych rozwiązań. Te rozwiązania nie podważają wprawdzie doktryny, ale prowadzą jedynie do zmiany podejścia duszpasterskiego. Chodzi dokładnie o „wzmocnienie i pogłębienie rozwiązań duszpasterskich" w odniesieniu do osób znajdujących się $\mathrm{w}$ nieregularnych sytuacjach małżeńskich. Skala tych zmian pozwala mówić wręcz o rewolucji pastoralnej Kościoła.

Nawet jeśli w adhortacji Franciszka nie została wprost zakwestionowana zasada nierozerwalności małżeństwa, to niepokój pozostaje. To nie jest tak, że zmiana podejścia duszpasterskiego nie narusza doktryny ${ }^{10}$. Rozwiązania duszpasterskie Kościoła i prawda w nim nauczana stanowią nierozerwalną całość. Wymuszone uwarunkowaniami społecznymi poluzowanie dyscypliny sakramentalnej wobec osób znajdujących się w sytuacji nieregularnej dotyka także doktryny sakramentalnej Kościoła. Konsekwencje są poważne. Zdaniem kardynała Saraha określone nawet mianem „niebezpiecznej herezji”, „schizofrenicznej patologii”11. Zdaniem innego, byłego już prefekta dykasterii watykańskiej, kardynała Gerharda Müllera, uniezależnianie praktyki duszpasterskiej od przekazu wiary jest tak samo niemożliwe, jak próba przeciwstawienia Chrystusa Nauczyciela prawdy i Chrystusa Dobrego Pasterza, który oddaje swoje życie za owce ${ }^{12}$.

Było to jednak rozstrzygnięcie jednoznaczne. Inaczej jest w przypadku papieża Franciszka. Jego adhortacja powiększyła zamieszanie i niepewność odnośnie do nauczania Kościoła na temat dostępu do sakramentów osób znajdujących się sytuacjach nieregularnych (na ten temat także G. MARENGO, Humanae vitae e Amoris laetitia, storie paralelle, https://www.lastampa. it/2017/03/23/vaticaninsider/humanae-vitae-e-amoris-laetitia-storie-parallelea [24.03.2019].

${ }^{10}$ Więcej na ten temat J. WoJTKUN, Sytuacja osób rozwiedzionych żyjacych w zwiazkach cywilnych wobec sakramentów. Przeglad komentarzy na temat ósmego rozdziału „Amoris laetitia", w: M. JAGODZIŃSKI (red.), Kwestie dyskutowane dzisiaj, Radom: Wydawnictwo AVE 2017, s. 31-52.

${ }^{11}$ Por. M. TosAtTi, Sarah, Sinodo: no all'eresia, „La Stampa” 24 febbraio 2015, http:// www.lastampa.it/2015/02/24/blogs/san-pietro-e-dintorni [20.06.2016].

12 Por. „Berrieren abbauen”. Gespräch mit dem Präfekten der Glaubenskongregation Kardinal Gerhard Ludwig Müller, „Herder Korespondenz” 6(2016), s. 19. 
Samo zresztą pojęcie „doktryna” naznaczone jest sporą dozą nieufności i obawą o to, że jej wymogi zostaną sprowadzone do kategorii ideału znajdującego się poza zasięgiem człowieka. Tak też stało się z nauczaniem na temat małżeństwa, konstatuje papież Franciszek w swojej adhortacji. Było ono przekazywane wiernym językiem czysto normatywnym, prowadząc do „nadmiernej idealizacji” małżeństwa. Bywało, że „przedstawialiśmy ideał teologiczny małżeństwa jako zbyt abstrakcyjny, skonstruowany niemal sztucznie, daleki od konkretnej sytuacji i rzeczywistych możliwości rodzin takimi, jakimi są"13. Bezpieczniej byłoby operować terminem: „rozwiązania duszpasterskie”. Zasady bowiem mogą stać się kamieniami, którymi „rzuca się w życie innych osób" ${ }^{14}$. Chcąc uniknąć posądzenia o małostkowość trzeba unikać zestawiania działania osoby z nadrzędnym, bardziej ogólnym prawem moralnym $^{15}$. Określenie zasad postępowania nie jest już wynikiem zestawienia z prawem moralnym, trzeba ją wyprowadzić z refleksji nad rzeczywistością. To ona teraz określa normy i zasady postępowania.

W metodzie przyjętej przez Humanae vitae prawda moralna definiuje rzeczywistość. Amoris laetitia zmienia tę kolejność: praktyka jest punktem wyjścia dla prawdy, a nawet ją warunkuje. Według tej metody powinniśmy teraz dokonać ponownej lektury Humane vitae. Punktem wyjścia powinny być nie normy moralne, ale refleksja nad zmienną rzeczywistością, w jakiej żyje dziś małżeństwo i rodzina. Potrzebny jest nowy klucz hermeneutyczny do lektury encykliki Papieża VI, według optyki wskazanej przez Franciszka w Amoris laetitia. Właśnie tak brzmiał tytuł jednego z wystąpień na wspomnianym już cyklu wykładów na papieskim uniwersytecie Gregorianum w Rzymie: „Przeczytać na nowo Humanae vitae według optyki Amoris laetitia". Po upływie pięćdziesięciu lat mamy nową sytuację, która rodzi konieczność ponownego odczytania zawartego w niej nauczania ${ }^{16}$. Pięćdziesiąt lat, jakie dzielą dwa dokumenty, to nie tylko epoka zmian, ale rzeczywista „zmiana epok”17.

13 AL 36.

14 AL 305.

15 AL 304.

${ }^{16}$ Wykład ten wygłosił 14 grudnia 2018 r. profesor Fakultetu Teologicznego w Mediolanie Maurizio Chiodi, zaś jego włoski tytuł brzmiał: Rileggere „Humane vitae” (1968) a partire da „Amoris Laetitia” (2016). Z pełnym tekstem prelekcji można zapoznać się na http://magist er.blogautore.espresso.repubblica.it/2018/01/28/rileggere-humanae-vitae-alla-luce-di-amorislaetitia/ [4.01.2019].

${ }^{17}$ To powszechnie już przywoływane stwierdzenie papieża Franciszka pojawiło się po raz pierwszy w wywiadzie udzielonym dziennikowi „Il Messaggero” w czerwcu 2014 roku. Został on następnie przedrukowany przez „L'Osservatore Romano” (30.06.2014) pod tytułem Cambio 
Ten nowy model myślenia nie bierze się znikąd. Zwłaszcza młode pokolenie ulega takiemu stylowi, który w miejsce prawdy przyznaje prymat użyteczności. Już nie prawda określa to, co jest wartościowe, przydatne, ale funkcjonalność i praktyka decyduje o prawdzie. Czyli: jeśli coś jest użyteczne, przydatne, uznane jest za prawdziwe, jeśli nie, odrzucane jako fałszywe. Takie myślenie przekłada się też na recepcję Ewangelii, z dramatycznymi tego konsekwencjami. „Wielu duszpasterzy wyznaje zasadę, że jeśli coś jest prawdziwe, to będzie działać. Nie przejmujmy się - mówimy, róbmy swoje. Ewangelia jest skarbem. Ona się sama obroni. A młodzi mają zupełnie odwrotną zasadę. Jeżeli coś działa, to jest prawdziwe. W ich odbiorze często Ewangelia nie jawi się jako prawdziwa, bo nie jest użyteczna do życia. I tu jest miejsce rozejścia"18. Jednym ze skutków tej zamiany miejsc prawdy z praktyką jest nowy sposób posługiwania się terminem grzechu.

\section{KONCEPCJA GRZECHU \\ W KONTEKSCIE KRYZYSU WIARY W STWORZENIE}

W czasie zorganizowanej przez Stowarzyszenie Moralistów Polskich Konferencji na temat Amoris laetitia, ojciec profesor Andrzej Derdziuk dokonał analizy sposobu, w jaki papież Franciszek posługuje się słowem „grzech”19. Pojęcie to pojawia się $\mathrm{w}$ adhortacji o rodzinie siedemnaście razy. Nie znajdziemy w niej żadnej definicji grzechu. Dominuje przy tym podejście psychologiczne i socjologiczne, ze szkodą dla wymiaru antropologicznego grzechu. Nie ma też odniesienia grzechu do konkretnego czynu, mowa jest raczej o grzechu w znaczeniu społecznym. Są to grzechy języka, takie jak oszczerstwa $^{20}$, lub grzechy przeciwko środowisku naturalnemu ${ }^{21}$. Mówi się o grzechu w sytuacjach małżeńskich zwanych ,nieregularnymi” (zawsze w cudzysłowie!), ale one nie zawsze oznaczają stan grzechu śmiertelnego. A to ze względu na okoliczności łagodzące odnoszące do podmiotu. Nie wychodzimy

d'epoka, http://www.osservatoreromano.va/it/news/cambio-depoca [3.01.2019].

${ }^{18}$ K. PAWLina, Jak postużyć mtodemu pokoleniu Polaków?, „Wiadomości Archidiecezjalne Warszawskie" (lipiec-grudzień) 2018, s. 140.

19 Por. J. PoDZIELNY, Sprawozdanie z ogólnopolskiej konferencji naukowej Implikacje teologiczno-moralne adhortacji „Amoris laetitia”, Nysa 11-13 czerwca 2017 roku, „Teologia i Moralnośćc" 12(2017), s. 344.

20 AL 112.

${ }^{21}$ AL 26. 
zatem poza wymiar horyzontalny grzechu (człowiek-człowiek), mniej widoczny jest wymiar wertykalny (człowiek-Bóg). Odniesienie do Boga w wymiarze teologalnym pojawia się sporadycznie: mowa jest o zestawieniu grzechu z miłością Jezusa ${ }^{22}$, oraz o zanurzeniu grzechu w Bożym miłosierdziu ${ }^{23}$. $\mathrm{W}$ innym miejscu dokumentu grzechem nazwane jest ,usiłowanie zastąpienia Stwórcy" zachodzące przy próbie oddzielenia od siebie płci biologicznej i społeczno-kulturowej ${ }^{24}$.

Natomiast wymiar teologalny grzechu stanowi konsekwentną bazę argumentacji Humanae vitae uzasadniającą moralną ocenę antykoncepcji. Nie wyczerpuje jej całości, ale stanowi punkt wyjścia. „W pełnieniu obowiązku przekazywania życia nie mogą oni (małżonkowie) postępować dowolnie, tak, jak gdyby wolno im było na własną rękę i w sposób niezależny określać poprawne moralnie metody postępowania: przeciwnie, są oni zobowiązani dostosować swoje postępowanie do planu Boga-Stwórcy, wyrażonego z jednej strony w samej naturze małżeństwa oraz w jego aktach, a z drugiej - określonego w stałym nauczaniu Kościoła"25.

Poszczególne etapy w procesie uzasadnienia grzesznego charakteru antykoncepcji wyraźnie nawiązują do wiary w dogmat stworzenia. Punktem wyjścia jest uznanie statusu człowieka jako stworzenia, które wyszło z rąk Boga. Człowiek jest dziełem Boga Stwórcy. We współżyciu małżeńskim człowiek staje się współpracownikiem Boga w dziele stworzenia. Rodzice w akcie małżeńskim „współstwarzają” dziecko razem z Bogiem, a zatem nie do nich należy arbitralne decydowanie o kształcie tego aktu. $\mathrm{Z}$ taką arbitralnością mamy natomiast do czynienia przy stosowaniu antykoncepcji. Pozbawia ona akt seksualny jego prokreacyjnego wymiaru, tym samym wyklucza Boga Stwórcę z przestrzeni jego stwarzającej obecności. Ignoruje Boga, wyrzuca Go $\mathrm{z}$ należnej Jemu samemu przestrzeni ${ }^{26}$.

Mamy w tej linii argumentacyjnej stałe ukierunkowanie na Boga Stwórcę. Rodzice są współpracownikami Boga, użytkownikami źródeł życia, nie zaś

${ }^{22}$ AL 64.

23 AL 211.

${ }^{24}$ AL 56.

${ }^{25} \mathrm{HV} 10$.

${ }^{26}$ Wątek ten został szeroko omówiony w: J.M. IBÁÑEZ LANGLOIS, The Theological argument at the basis of „Humanae vitae”, w: PONTIFICIO IstitUTO GIOVANNI PAOLO II PER STUDI Su Matrimonio E Familia Università Lateranese, CEnTro ACCADEMico Romano della SAnta Croce, Università di NAVArRA, „Humanae vitae”. 20 anni dopo. Atti del II Congresso Internazionale di Teologia Morale (Roma, 9-12 novembre 1988), Milano: Edizioni Ares 1989, s. $115-122$. 
jego właścicielami i zarządcami. Przy antykoncepcji dochodzi do odwrócenia tego porządku. „Małżonkowie nie uważają się już za sługi Bożego planu, ale sami stawiają się w miejsce Pana Boga, uważając się za prywatnych właścicieli swojej płodności. Przywłaszczają sobie cały autorytet decydujący o zaistnieniu życia i jego przeznaczeniu"27.

Jest to jeden z przejawów zatraty wrażliwości na prawdę wiary w stworzenie. Już w latach osiemdziesiątych ubiegłego wieku źródło zagrożeń dla życia ludzkiego kardynał Ratzinger upatrywał w zagubieniu przesłania o stworzeniu. W obliczu tej sytuacji na wiosnę 1981 roku wygłosił w katerze monachijskiej cztery katechezy poświęcone implikacjom prawdy o stworzeniu. W niezrozumieniu tej prawdy, a nawet $\mathrm{w}$ jej odrzuceniu, upatruje ówczesny arcybiskup Monachium źródło dzisiejszych grzechów przeciw życiu człowieka, w tym także grzechów przeciw płodności. „Możemy powiedzieć, że najgłębszą treścią grzechu jest to, że człowiek chce zaprzeczyć faktowi bycia stworzonym, gdyż nie chce przyjąć miary i granicy, które są w nim zawarte. Człowiek nie chce być stworzeniem, nie chce być zależny, nie chce mieć miary. Swoją zależność od Bożej miłości interpretuje jako poddanie, a poddanie jest niewolą; z niewoli zaś trzeba się wyzwolić" 28 .

Wiele miejsca w uzasadnieniu zakazu antykoncepcji przywiązywano do argumentacji podanej w numerze 12. encykliki Humane vitae, odnoszącej się do jedności wymiaru prokreacyjnego i zjednoczeniowego współżycia małżeńskiego. Ten aspekt przeważał na wykładach z teologii moralnej w czasie, kiedy autor tego artykułu był jeszcze alumnem seminarium. Mniej uwagi poświęcano argumentowi odwołującemu się do prawdy o stworzeniu, która określa kształt małżeńskiego powołania do przekazywania życia i ubogaca je o istotny rys antropologiczny. Być może to był powód, dla którego Benedykt XVI, już jako papież senior przyznał, że miał zastrzeżenia do sposobu argumentacji przyjętej przez Pawła VI w Humane vitae. Wyznał po latach: „Był dla mnie niezadowalający. Poszukiwałem szerszego antropologicznego spojrzenia. Natomiast Papież Jan Paweł II uzupełnił prezentowane w niej ujęcie naturalnoprawne wizją personalistyczną"29.

27 W. GuBAŁA, Ocena antykoncepcji w świetle nauczania Kościoła Katolickiego, http:// www.srk.opoka.org.pl/srk/srk_pliki/dokumenty/art3.html [20.03.2019].

28 J. RATZINGER - BENEDYKT XVI, Cztery kazania o stworzeniu i upadku. Na poczatku Bóg stworzyt.... Konsekwencje wiary w stworzenie, Kraków: Salwator 2006, s. 73.

${ }^{29}$ BenedyKt XVI, Ostatnie rozmowy. Peter Seewald, Kraków: Rafael 2016, s. 186-187. 


\section{AUTORYTET SUMIENIA A MAGISTERIUM KOŚCIOŁA}

Kwestia odniesienia głosu sumienia do obiektywnego prawa moralnego to kolejna płaszczyzna, na której dostrzegamy różnice w metodzie wykładu nauki moralnej omawianych dokumentów. Należy w tym miejscu wspomnieć o wkładzie kardynała Karola Wojtyły w kształt encykliki Pawła VI. Rola Karola Wojtyły nie ograniczała się tylko do uzupełniania braków argumentacyjnych Humanae vitae. Przyszły Papież miał swój znaczny udział w ostatecznej redakcji dokumentu Pawła VI. Jego wyrazem jest doręczony papieżowi w lutym 1969 roku tzw. „Memoriał krakowski”, czyli „Uzasadnienie katolickiej nauki tyczącej podstaw moralnych życia małżeńskiego"30. Choć sam dokument jest owocem pracy grupy teologów moralistów, głównie ze środowiska krakowskiego, to kardynał Wojtyła czynnie uczestniczył w jego redakcji poprzez udział $w$ dyskusjach i wysuwane inspiracje ${ }^{31}$. Kardynał Wojtyła zredagował natomiast w 1969 roku osobisty list do papieża. Zawierał on sugestie wątków pomocnych w opracowaniu instrukcji pastoralnej dla duszpasterzy i osób świeckich ułatwiających recepcję nauczania encykliki. Jest $\mathrm{w}$ tym liście osobny fragment poświęcony roli sumienia w odniesieniu do prawa moralnego nauczanego przez Kościół. „Sumienie czerpie swą zobowiązującą i decydującą moc normatywną $\mathrm{z}$ obiektywnego prawa moralnego. Jest to prawo Boże, a jeśli ludzkie - to także zakorzenione w Bożym, które jest albo formalnie objawione albo zawarte w prawie natury. To prawo Paweł VI przypomina i wyjaśnia również w encyklice Humanae vitae. W związku z tym nie można przyjąć, aby było moralnie prawe postępowanie katolika, który - mając pełną świadomość doktryny moralnej Kościoła - postępowałby wbrew poznanym normom, w oparciu o subiektywny osąd własnego sumienia"32. Wartość moralna czynu kształtowana jest w oparciu o normę moralności. „Czyny zgodne z tą normą są moralnie dobre, czyny jej przeciwne, niezgodne z nią - moralnie złe. Norma ta należy do prawa naturalnego, czyli

${ }^{30}$ Dość powiedzieć, że omówienie wpływu Karola Wojtyły na tekst Humane vitae wystarczyło na przygotowanie pracy doktorskiej ks. Pawła Stanisława Gałuszki i wydanej potem książki o objętości bez mała 500 stron. Wersja polska nosi tytuł: Karol Wojtyta $i$ „Humanae vitae”, Kraków: Muzeum Jana Pawła II i Prymasa Wyszyńskiego 2018. Bardziej jednak wymowny dla podkreślenia roli Karola Wojtyły jest tytuł włoskiej wersji dzieła: Karol Wojtyła $e$ „Humanae vitae”. Il contributo dell'Arcivescovo di Cracovia e del gruppo di teologi polacchi all'anciclica di Paolo VI, Siena: Cantagalli 2017.

${ }^{31}$ Por. tamże, s. 495, przypis 1.

${ }^{32}$ Kard. K. WojtYŁA, List do papieża Pawta VI (1969), w: P. GAŁuSZKA. Karol Wojtyła $i$ „Humanae vitae”, s. 505. 
że odpowiada samemu rozumowi. Kościół naucza tej normy, choć nie zawiera się ona formalnie (czyli w znaczeniu dosłownym) w samym Piśmie Świętym - naucza jej więc, kierując się przekonaniem, że objaśnienie nakazów prawa naturalnego należy do kompetencji nauczycielskiej Kościoła"33.

W rozeznawaniu moralnej wartości czynu sumienie powinno dostosować się do wykładni naturalnego prawa moralnego dokonywanej autorytatywnie przez Magisterium Kościoła. „Zapewne nikt z wiernych nie zamierza przeczyć, że w kompetencjach Nauczycielskiego Urzędu Kościoła leży interpretowanie naturalnego prawa moralnego. [...] Prawo bowiem naturalne jest również wyrazem woli Bożej i jego wierne przestrzeganie jest ludziom konieczne do zbawienia" ${ }^{34}$. Po stronie duszpasterzy w sprawach moralności rodzi to obowiązek posłuszeństwa Nauczycielskiemu Urzędowi Kościoła ${ }^{35}$. Sumienie w rozeznawaniu wartości moralnej czynu potrzebuje światła. Jest nim nauczanie Kościoła. Rola sumienia prawego polega na byciu „prawdziwym tłumaczem obiektywnego porządku moralnego" ${ }^{36}$. Prawdziwy tłumacz bywa określany tłumaczem ,przysięgłym”, czyli takim, który tłumaczone treści przekazuje wiernie, bez zafałszowania.

Umieszczenie w tekście encykliki apelu o posłuszeństwo rozstrzygnięciom w sprawie antykoncepcji nie zapobiegło interpretacjom niezgodnym z zamysłem papieża. W miejsce sumienia ,tłumacza” porządku moralnego niektóre konferencje biskupów wprowadzały koncepcję sumienia „kreatora” norm moralnych. W tym ujęciu norma moralna przestaje pełnić rolę nadrzędną w stosunku do sumienia. Rolą sumienia nie jest już osąd, lecz decyzja, nie lektura norm zawartych w prawie moralnym, ale ich tworzenie, w zależności od zmiennych sytuacji.

Najszybciej na dokument Pawła VI zareagował episkopat niemiecki. Miesiąc po ogłoszeniu encykliki swoje stanowisko ogłosił w tzw. Königsteiner Erklärung (Deklaracja z Königstein). Wyjaśnił w niej, że wierni mogą we własnym sumieniu opowiedzieć za przyjęciem lub odrzuceniem nauczania Humane vitae ${ }^{37}$. W podobnym tonie wypowiedzieli się biskupi austriaccy. W deklaracji podpisanej w sanktuarium maryjnym Maria-Trost stwierdzili, że jeśli ktoś, mający kompetencje w ocenie antykoncepcji, dojdzie w sumieniu do odmiennego niż Paweł VI rozeznania, to wolno mu stosować antykoncep-

33 JAN PAWEE II. Objaśnienie nakazów prawa naturalnego. Katecheza 18 lipca 1984, w: Jan PaWee II, Dzieta zebrane, t. VI, Kraków: Wydawnictwo M 2007, s. 413.

${ }^{34} \mathrm{HV} 4$.

${ }^{35}$ Por. HV 28.

${ }^{36} \mathrm{HV} 10$.

37 Tekst deklaracji z 30 sierpnia 1968 dostępny jest na stronie: kathpedia.com. 
cję, byleby nie zachęcał do niej innych ${ }^{38}$. Promowana przez biskupów kontestujących papieski dokument wizja sumienia kreatywnego stała się głównym przesłaniem głośnej przed laty tzw. „Deklaracji Kolońskiej”, dokumentu podpisanego przez grupę pięciuset teologów z uniwersytetów krajów niemieckojęzycznych. „W przekonaniu wielu osób w Kościele, normy kontroli urodzeń zawarte w encyklice Humanae vitae z 1968 r. stanowią pewną orientację, która nie zastępuje odpowiedzialności sumienia samych wiernych. Biskupi, m.in. biskupi niemieccy w swej «Deklaracji z Königstein» (1968 r.) i teologowie moraliści uznali ten pogląd chrześcijanek i chrześcijan za słuszny, gdyż są przekonani, że godność sumienia nie polega tylko na posłuszeństwie, lecz właśnie na odpowiedzialności”39.

Niezmiennie krytyczne stanowisko wobec takiej koncepcji roli sumienia wobec prawa moralnego przekazywanego przez Kościół zajmował Jan Paweł II. Uczynił to w sposób najbardziej autorytatywny w encyklice Veritatis splendor (w adhortacji papieża Franciszka nie ma do niej ani jednego odniesienia). Po przedstawieniu szerokiej panoramy stanowisk uzasadniających kreatywną rolę sumienia Jan Paweł II stwierdza: „Trudno nie zauważyć, że tezy te podważają samą tożsamość sumienia w jego relacji do wolności człowieka i prawa Bożego. Tylko przedstawione wcześniej wyjaśnienia na temat więzi między wolnością a prawem, opartej na prawdzie, umożliwiają właściwą ocenę tej kreatywnej koncepcji sumienia"

W tym miejscu trudno oprzeć się wrażeniu, że wizja sumienia, odrzucona przez Jana Pawła II, powraca w adhortacji papieża Franciszka. Lektura dokumentu papieża Franciszka ,przede wszystkim ze względu na niejednoznaczność, każe postawić pytanie o możliwość «wpisania»w adhortację takiej interpretacji, która dopuszcza istnienie sumienia kreatywnego w sytuacjach tak zwanych małżeństw nietypowych" ${ }^{\text {. }}$. W dużej mierze taki wniosek opiera się na zastosowaniu przez papieża Franciszka konsekwentnie używanego klucza antropologicznego. Dotyczy on roli rozumu i poznania w strukturze moralnej człowieka. Papież uznaje je za niewystarczające do wypracowania

${ }^{38}$ Stanowisko biskupów austriackich z września 1968 można znaleźć na stronie www.stjo sef.at. Swoistym paradoksem jest wybór miejsca podpisania deklaracji: sanktuarium Matki Bożej Pocieszenia, niekoniecznie ,pocieszonej” decyzją austriackich biskupów.

39 Powyższy fragment przywołany za: P. BoRTKIEWICZ, Kreatywne sumienie $w$ „Amoris laetitia”?, „Teologia i Moralność” 2018, nr 1(23), s. 62.

40 VS 56.

${ }^{41}$ P. BortKiewicz, Kreatywne sumienie w „Amoris laetitia”?, s. 61. 
właściwego osądu ${ }^{42}$. Treści doktrynalne wzbogacają wiedzę na temat dobra i zła, ale wymagają dopełnienia. „Przez długi czas byliśmy przekonani, że jedynie kładąc nacisk na kwestie doktrynalne, bioetyczne i moralne, nie pobudzając do otwartości na łaskę, dostatecznie wsparliśmy rodziny, umacniając więź małżonków i wypełniliśmy sensem ich wspólne życie"43. Potrzebne jest zatem poszerzenie perspektywy antropologicznej roli sumienia o czynniki pozarozumowe. One to pozwalają dostrzec, że postępowanie moralne jest nie tylko zgodne z wiedzą o dobru, ale jest korzystne dla samej osoby. ,Jakkolwiek sumienie dyktuje nam określony osąd moralny, czasami większą władzę mają inne rzeczy, które nas pociągają, jeśli nie udało nam się dojść do tego, aby dobro zrozumiane przez umysł zakorzeniło się w nas jako głęboka skłonność emocjonalna, jako zamiłowanie do dobra, które ma większe znaczenie niż inne atrakcje i pozwala nam dostrzec, że to, co pojęliśmy jako dobro, jest także dobrem «dla nas» tu i teraz"44.

Nie lekceważymy oczywiście roli emocji w poznaniu moralnym. Dobro ma moc przyciągania, rodzi, zdaniem papieża, „głęboką skłonność emocjonalną”. Czy jednak nie wpadamy tutaj w pułapkę subiektywizmu, skoro ,większą władzę mają inne rzeczy"? Emocje są czymś bardzo indywidulanym, subiektywnym, poznanie prawdy o dobru jest obiektywne. Ale nie zawsze wystarczy. Przy wypracowaniu osądu sytuacji osób żyjących w związkach nieregularnych sumienie ,może uznać nie tylko to, że dana sytuacja (nieregularna) nie odpowiada obiektywnie ogólnym postanowieniom Ewangelii”. Efektem tego rozeznania nie jest już skorygowanie niewłaściwej postawy, ale uznanie jej wręcz za ,dar, jakiego wymaga sam Bóg pośród konkretnej złożoności ograniczeń, chociaż nie jest to jeszcze w pełni obiektywny ideał"45.

Trudno oprzeć się wrażeniu, że mamy tu do czynienia z dopuszczaniem przez Franciszka kreatywnej roli sumienia ${ }^{46}$. A to wiąże się z dalszymi konsekwencjami. Jedną $\mathrm{z}$ nich jest rewizja nauczania na temat istnienia aktów wewnętrznie

42 Por. M. SzCZODRY, Kwestia sumienia w posynodalnej adhortacji apostolskiej „Amoris laetitia” papieża Franciszka, w: G. CHOJNACKI (red.), Mitość jest nam dana i zadana. Komentarz do posynodalnej adhortacji apostolskiej „Amoris laetitia” papieża Franciszka, Szczecin: Wydawnictwo Naukowe Uniwersytetu Szczecińskiego 2017, s. 248-249.

${ }^{43}$ AL 37.

${ }^{44}$ AL 265.

45 AL 303.

${ }^{46}$ Do takiego samego wniosku dochodzi też P. Bortkiewicz (Kreatywne sumienie w „Amoris laetitia”, s. 73). 
złych, czyli takich, których nie wolno podejmować niezależnie od ewentualnych intencji osoby działającej lub towarzyszących im okoliczności.

\section{AKTY WEWNĘTRZNIE ZŁE A PRAWO STOPNIOWALNOŚCI}

Zgodnie z nauką Papieża Pawła VI, antykoncepcja należy do działań, które ze swej natury nigdy nie moga zostać uznane za godziwe. „Nie wolno wziąć za przedmiot aktu woli tego (kontekst wskazuje na antykoncepcję), co ze swej istoty narusza ład moralny - a co tym samym należy uznać za niegodne człowieka nawet $\mathrm{w}$ wypadku, jeśli zostaje to dokonane w zamiarze zachowania lub pomnożenia dóbr poszczególnych ludzi, rodzin czy społeczeństwa"47.

Dwadzieścia lat póńniej wykładnię tę potwierdził papież Jan Paweł II: „Paweł VI, kwalifikując działanie antykoncepcyjne jako wewnętrznie niedopuszczalne (intrinscecamente illecito), zamierzał potwierdzić, że norma moralna nie dopuszcza wyjątków: żadna okoliczność osobista lub społeczna, nigdy nie mogła, nie może i nie będzie mogła uczynić wewnętrznie uporządkowanym taki akt”48.

W Amoris laetitia o czynach wewnętrznie złych się nie mówi. Może dlatego, że jest to dokument o radości miłości. Jednak temat udziału przedmiotu, intencji i okoliczności w określaniu odpowiedzialności moralnej został podjęty, i to w dość zaskakujący sposób. O ile czynem wewnętrznie złym w Humane vitae jest stosowanie antykoncepcji, to w Amoris laetitia ich odpowiednikiem są sytuacje związków zwanych „nieregularnymi” (w dokumencie zawsze w cudzysłowie). Nie pojawiają się jednak przykłady czynów osób żyjących w takich związkach. Z kontekstu przypisu 329 można wywnioskować, że chodzi o akty będące wyrazami intymności małżeńskiej ${ }^{49}$.

Czy mogą być one nazwane czynami wewnętrznie złymi, których wyboru nie można niczym usprawiedliwić? Otóż adhortacja opowiada się za istnieniem takich okoliczności, które co prawda nie przekształcają ich związek w regularny,

47 HV 14.

48 JAN PAWE⿺ II, Discorso al II Congresso Internazionale di Teologia Morale (Roma 12 Novembre 1988), w: Pontificio Istituto Giovanni PAOlO II PER STUDi SU MATRIMONIO e Familia Università Lateranese, Centro accademico Romano della Santa Croce, UNIVERSITÀ DI NAVARRA, „Humanae vitae”. 20 anni dopo, s. 10.

49 AL 298. W przypisie tym znajduje się odwołanie do tekstu Konstytucji soborowej Gaudium et spes: ,W tych sytuacjach wielu, znając i przyjmując możliwość pozostawania w związku «jak brat i siostra», którą oferuje im Kościół, odkrywają, że jeśli brak pewnych wyrazów intymności «nierzadko» wierność może być wystawiona na próbę, a dobro potomstwa zagrożone" (nr 51). 
to jednak mogą łagodzić negatywną ocenę moralną. Co więcej, te okoliczności mają moc przekwalifikowania grzechu ciężkiego w grzech lekki. „Nie można już powiedzieć, że wszyscy, którzy są w sytuacji tak zwanej «nieregularnej», żyją W stanie grzechu śmiertelnego, pozbawieni łaski uświęcającej" ${ }^{50}$. W konsekwencji pożycie seksualne osób, tworzących związek nieregularny, byłoby nieporządkiem moralnym, ale tylko na poziomie grzechu lekkiego. Skoro zaś, zgodnie z nauką Katechizmu Kościoła Katolickiego, nie ma obowiązku spowiadania się z grzechów lekkich, to można by przystępować do Komunii Świętej nawet nie wyznając tych grzechów na spowiedzi ${ }^{51}$.

Idąc dalej tym tropem rozumowania wpadamy w kolejną pułapkę, jaką jest opowiedzenie się po stronie teorii stopniowości prawa. Obawy są uzasadnione. Prawo jasno określa czym jest cudzołóstwo (słowo „cudzołóstwo” ani razu nie pojawia się $\mathrm{w}$ adhortacji) i na czym polegają niezgodne $\mathrm{z}$ Ewangelią formy wspólnego życia. Przyjmując, że utrwalona forma ich naruszenia w postaci konkubinatu nie musi być grzechem śmiertelnym, opowiadamy się po stronie zróżnicowanego obowiązku wierności prawu.

Zdaniem Jana Pawła II w prawie Bożym nie istnieją stopnie rodzące różny zakres obowiązku. Prawo Boże, choć wymagające, to zobowiązuje każdego do wytrwałego pokonywania trudności w dochodzeniu do jego pełnego wypełnienia. Nie może być zatem traktowane jako czysty ideał do osiagnięcia jedynie w odległej przyszłości ${ }^{52}$. Papież Franciszek przyznaje, że podziela to rozstrzygnięcie Jana Pawła II. Tymczasem są w adhortacji miejsca świadczące o czymś przeciwnym. Perspektywa antropologiczna, zaprezentowana przez Papieża Franciszka, zdaje się w niewystarczającym stopniu uwzględniać znaczenie łaski. Łaska i jej rola w życiu moralnym zabezpiecza teologię moralną przed sprowadzeniem jej do etyki filozoficznej. Tymczasem z numeru 122. adhortacji papieża Franciszka wynika, że ideał doskonałego związku między Chrystusem a Kościołem może być „ogromnym ciężarem”, którego nie należy narzucać na osoby mające przecież swoje ograniczenia. Czymże to jest, jeśli nie stopniowością prawa i ograniczaniem moralnych wymagań tylko do możliwości naturalnych człowieka? $\mathrm{Na}$ jakiej podstawie możemy rozstrzygać czy dążenie do odtworzenia w małżeństwie doskonałego związku Chrystusa z Kościołem jest ciężarem ponad miarę, czy jednak zgodnym z miarą możliwości człowieka. Dodajmy - człowieka odkupionego i na miarę możliwości małżonków, którzy w sakramencie małżeństwa zo-

50 AL 301.

${ }^{51}$ Por. R. PLICH, Legalistyczna neutralizacja nauki o czynach wewnętrznie złych, ,Teologia i Moralność" 2018, nr 1(23), s. 98.

52 Por. FC 34. 
stali ubogaceni łaską Chrystusa. Czy wolno w świetle tej prawdy poprzestać na tym, co w zasięgu tylko ludzkich możliwości? A może właśnie do miłości małżeńskiej należałoby odnieść zapewnienie Jana Pawła II: „Człowiek nie potrafi o własnych siłach naśladować i przeżywać miłości Chrystusa. Staje się zdolny do takiej miłości jedynie mocą udzielonego mu daru"53.

Refleksje, zawarte w niniejszym artykule, były zainspirowane pytaniem określonym w tytule: Czy po pięćdziesięciu latach upływających od ogłoszenia encykliki Humane vitae spotykamy się w nauczaniu Franciszka w Amoris laetita z kontynuacją czy nową interpretacją moralności? To prawda, że obydwa dokumenty różnią się tematyką, ale sposób podejmowania problemów moralnych można ze sobą zestawić. Takiego zestawienia dokonali już polscy biskupi: „Amoris laetitia nie tylko uwzględnia, ale nade wszystko dopełnia i aktualizuje wcześniejsze wypowiedzi Magisterium Kościoła na temat małżeństwa i rodziny. Wśród wcześniejszych dokumentów programowych należy wymienić Humanae vitae Pawła VI, Familiaris consortio, Reconcilliatio et poenitentia, Veritatis splendor Jana Pawła II oraz Deus caritas est i Sacramentum caritatis Benedykta XVI. Nie ulega więc wątpliwości, że papież Franciszek w adhortacji Amoris laetitia w żaden sposób nie podważa nauczania swych Poprzedników. Wyraźnie uznaje konieczność istnienia w Kościele jedności doktryny i działania, która jednak nie wyklucza istnienia «różnych sposobów interpretowania pewnych aspektów nauczania lub niektórych wynikających z niego konsekwencji» (AL 3)",54.

Właśnie te różne sposoby interpretowania pewnych aspektów nauczania prowadzą do wniosku, że adhortacja Franciszka w wielu punktach jest nowym paradygmatem moralności. Sposób podejmowania przez papieża wskazanych w niniejszej refleksji zagadnień nie świadczy bynajmniej o kontynuacji doktryny moralnej. Inna jest metoda wypracowywania wniosków, pewne terminy teologicznomoralne w ogóle się nie pojawiają, albo są ujęte w cudzysłów. Nie nazwiemy ich zerwaniem, ale nowym ujęciem, które może prowadzić do zamętu i niejednoznaczności w ocenie czynów ludzkich i sytuacji małżeńskich określanych jako nieregularne.

\footnotetext{
${ }^{53} \mathrm{VS} 22$.

${ }^{54}$ Wytyczne Pastoralne KEP do adhortacji „Amoris Laetitia”. https://episkopat.pl/biskupipotrzeba-sluzby-malzenstwu-i-rodzinie-oraz-osobom-w-zwiazkach-niesakramentalnych/.
} 


\title{
BIBLIOGRAFIA
}

\author{
ŹRÓDŁA \\ SOBÓR WATYKAŃSKI II, Konstytucja duszpasterska o Kościele Gaudium et spes (7.12.1965). \\ PAWE€ VI, Encyklika Humanae vitae (25.07.1968). \\ JAN PAWE€ II, Adhortacja Familiaris consortio (22.11.1981). \\ JAN PAWEŁ II, Objaśnienie nakazów prawa naturalnego. Katecheza 18.07.1984, w: JAN PA- \\ WE€ II, Dzieła zebrane, t. VI, Kraków: Wydawnictwo M 2007, s. 413-414. \\ JAN PAWEŁ II, Encyklika Veritatis splendor (6.08.1993). \\ FRANCISZEK, Adhortacja Amoris laetitia (19.03.2016).
}

\section{LITERATURA}

BENEDYKT XVI, Ostatnie rozmowy. Peter Seewald, Kraków: Rafael 2016.

„Berrieren abbauen”. Gespräch mit dem Präfekten der Glaubenskongregation Kardinal Gerhard Ludwig Müller, „Herder Korespondenz” 6(2016), s. 19.

BortKIEWICZ P., Kreatywne sumienie w Amoris laetitia?, „Teologia i Moralność” 2018, nr 1 (23), s. 61-74.

CERnuzio S., „L'Amoris Latitia” non mette in crisi la famiglia; è la crisi della famiglia che mette in moto la Chiesa. Il cardinale Farrell commenta l'esortazione del Papa, https://www. lastampa.it/2017/03/20/vaticaninsider/ita/vaticano/lamoris-laetitia-non-mette-in-crisi-la-famiglia-la-crisi-della-famiglia-che-mette-in-moto-la-chiesa

CHIODI M., Rileggere Humane vitae (1968) a partire da Amoris Laetitia (2016), http://magist er.blo gautore.espresso.repubblica.it/2018/01/28/rileggere-humanae-vitae-alla-luce-di-amoris-laetitia.

GaŁuszKa P., Karol Wojtyła i Humanae vitae, Kraków: Muzeum Jana Pawła II i Prymasa Wyszyńskiego 2018.

GaŁuszKA P., Karol Wojtyła e Humanae vitae. Il contributo dell'Arcivescovo di Cracovia e del gruppo di teologi polacchi all'anciclica di Paolo VI, Siena: Cantagalli 2017.

GubaŁA W., Ocena antykoncepcji w świetle nauczania Kościoła Katolickiego, http://www.srk. opoka.org.pl/srk/srk_pliki/dokumenty/art3.html.

IBÁÑEZ LANGLOIS J.M., The Theological argument at the basis of Humanae vitae, w: PONTIFICIO ISTITUTO GIOVANNI PAOLO II PER STUDI SU MATRIMONIO E FAMILIA UNIVERSITÀ LATERANESE, Centro AcCademico Romano della Santa Croce, Università di Navarra, Humanae vitae, 20 anni dopo. Atti del II Congresso Internazionale di Teologia Morale (Roma, 9-12 novembre 1988). Milano: Edizioni Ares 1989, s. 115-122.

MARENGO G., Humanae vitae e Amoris laetitia, storie paralelle, https://www.lastampa.it/2017/ 03/23/vaticaninsider/humanae-vitae-e-amoris-laetitia-storie-parallelea.

MoIA L., Discutere Humanae vitae? «No, riflettiamo sui temi». Sessualità e famiglia a 50 anni dall'enciclica. Alla Gregoriana un percorso per fare chiarezza, „L'Avvenire” 19.10.2017, s. 20.

PAWLINA K., Jak posłużyć młodemu pokoleniu Polaków?, „Wiadomości Archidiecezjalne Warszawskie" (lipiec-grudzień) 2018, s. 140.

PLICH R., Legalistyczna neutralizacja nauki o czynach wewnętrznie złych i absolutnych zakazach moralnych w adhortacji Amoris laetitia, „Teologia i Moralność” 2018, nr 1(23), s. 89-123.

PODZIELNY J., Sprawozdanie z ogólnopolskiej konferencji naukowej „Implikacje teologicznomoralne adhortacji Amoris laetitia”, Nysa 11-13 czerwca 2017 roku, „Teologia i Moralność" 2017, nr 2(22), s. 343-345. 
Ponad 500 katolickich naukowców w obronie encykliki Humanae vitae i za zakazem antykoncepcji, www.pch24.pl.

Od buntu wobec Humanae vitae do apologii Amoris laetitia, www.pch24.pl.

RATZINGer J.- BENEDYKT XVI, Cztery kazania o stworzeniu i upadku. Na początku Bóg stworzył.... Konsekwencje wiary w stworzenie, Kraków: Salwator 2006.

SCARAFFA L., Humanae vitae cinquant'anni dopo, „L'Osservatore Romano” 25.07.2018.

SzCZODRY M., Kwestia sumienia w posynodalnej adhortacji apostolskiej Amoris laetitia papieża Franciszka, w: G. ChoJnACKI (red.), Miłość jest nam dana i zadana. Komentarz do posynodalnej adhortacji apostolskiej Amoris laetitia papieża Franciszka, Szczecin: Wydawnictwo Naukowe Uniwersytetu Szczecińskiego 2017, s. 248-249.

TosATti M., Sarah, Sinodo: no all'eresia, „La Stampa” 24.02.2015, http://www.lastampa.it/201 5/02/24/blogs/san-pietro-e-dintorni.

WOJTKUN J., Sytuacja osób rozwiedzionych żyjących w związkach cywilnych wobec sakramentów. Przegląd komentarzy na temat ósmego rozdziału Amoris laetitia, w: M. JAGODZIŃSKI (red.), Kwestie dyskutowane dzisiaj, Radom: Wydawnictwo AVE 2017, s. 31-52.

Wytyczne Pastoralne KEP do adhortacji Amoris Laetitia, https://episkopat.pl/biskupi-potrzeba-sl uzby-malzenstwu-i-rodzinie-oraz-osobom-w-zwiazkach-niesakramentalnych/.

\section{KONTYNUACJA MYŚLI HUMANAE VITAE W POSYNODALNEJ ADHORTACJI AMORIS LAETITIA CZY NOWA INTERPRETACJA MORALNOŚCI?}

\section{STRESZCZENIE}

50 lat po ogłoszeniu encykliki Humanae vitae pojawił się postulat jej ponownej lektury w świetle metody zaproponowanej przez papieża Franciszka w adhortacji Amoris laetitia. Odczytanie na nowo nauczania papieża Pawła VI powinno uwzględnić nową perspektywę wychodzącą nie od norm moralnych, ale od opisu rzeczywistości, w jakiej znajdują się małżonkowie. Ta nowa optyka lektury Humanae vitae, zarysowana w Amoris laetitia, skłania do postawienia pytania: czy nauczanie papieża Franciszka jest kontynuacją czy nową interpretacją moralności? Wyraźne są różnice w podejmowaniu takich zagadnień, jak: istota grzechu, jego wymiar horyzontalny i wertykalny, istnienie aktów wewnętrznie złych. Inaczej niż Paweł VI podejmuje Franciszek zagadnienie sumienia i jego roli przy wyborach moralnych. Trudno oprzeć się wrażeniu, że zakwestionowana zdecydowanie przez Jana Pawła II koncepcja sumienia kreatywnego, pojawia się w uzasadnieniach moralnych papieża Franciszka. Natrafić też możemy na fragmenty adhortacji papieża Franciszka, które mogą świadczyć o opowiadaniu się po stronie koncepcji stopniowalności prawa, również zakwestionowanej w dotychczasowym nauczaniu Kościoła. Różne sposoby interpretowania pewnych aspektów nauczania moralnego prowadzą do wniosku, że adhortacja Franciszka w wielu punktach nie świadczy o kontynuacji doktryny moralnej, ale stanowi propozycję nowego paradygmatu moralności.

Słowa kluczowe: małżeństwo; norma; grzech; sumienie; prawo stopniowalności. 